Int. J. Dev. Biol. 57: 299-308 (2013)

doi: $10.1387 / \mathrm{ijdb} .13001711$

\title{
Role of epigenetics in the etiology of germ cell cancer
}

\author{
YVONNE G. VAN DER ZWAN', HANS STOOP', FERNANDO ROSSELLO², \\ STEFAN J. WHITE2,\#, LEENDERT H.J. LOOIJENGA ${ }^{1, \#}$

\begin{abstract}
${ }^{1}$ Department of Pathology, Erasmus MC - University Medical Center Rotterdam, Josephine Nefkens Institute, Rotterdam, The Netherlands, ${ }^{2}$ Centre for Cancer Research, Monash Institute of Medical Research, Monash University, Clayton and ${ }^{3} \mathrm{Centre}$ for
\end{abstract} \\ Reproduction and Development, Monash Institute of Medical Research, Monash University, Clayton, Victoria, Australia.
}

\begin{abstract}
Embryonic development is strictly controlled by functionality of genes in which the existing networks can act both on transcription and translation regulation. Germ cell cancers (GCC) are unique because of a number of characteristics. In spite of their clinical presentation, i.e., predominantly after puberty, they arise from primordial germ cells/gonocytes that have failed appropriate maturation to either pre-spermatogonia or oogonia. GCC mimic embryonal development to a certain extent, including capacity for totipotency. This knowledge has allowed the identification of informative diagnostic markers, including OCT3/4 (POU5F1), SOX2 and SOX17. An additional marker is the overall demethylated status of the genome. Genetic mutations in GCC are rare, which is exceptional for solid cancers. Our hypothesis is that a disturbed epigenetic regulation (through combined interaction of genetic or environmental parameters; referred to as genvironment) affect embryonic germ cell development, resulting in delayed or blocked maturation, and potentially progression to GCC. In this respect, studies of patients with Disorders of Sex Development (DSD) have increased our knowledge significantly. Genvironmental influences can lead to retention of existence of embryonic germ cells, the first step in the pathogenesis of GCC, resulting into the precursor lesions gonadoblastoma or carcinoma in situ. Identification of epigenetic alterations could lead to better understanding these processes and development of specific markers for early detection, eventually leading to development of targeted treatment. This review describes an interactive model related to the role of epigenetics in GCC pathogenesis, focusing on DNA methylation, histone modifications, epigenetic memory and inheritance, as well as environmental factors.
\end{abstract}

KEY WORDS: germ cell cancer, epigenetics, methylation, histone modification, environment

\section{Introduction}

Type II (testicular) germ cell tumors, referred to as Germ Cell Cancers (GCC), are the most common malignancy in Caucasian adolescents and young adults and their incidence is still rising (Huyghe et al., 2003, Huyghe et al., 2007). GCC arise from primordial germ cells (PGC) or gonocytes and are subdivided into seminomas/dysgerminomas and non-seminomas with carcinoma in situ (CIS) or gonadoblastoma (GB) as precursor lesions (Looijenga et al., 2011). Non-seminomas can be further categorized into embryonal carcinoma, which can differentiate into somatic lineages and extra-embryonic tissues (teratoma vs yolk sac tumor and choriocarcinoma respectively) (Looijenga et al., 2011). PGC have the intrinsic capacity for pluri/totipotency, reflected in GCC, in which even the germ line can be formed in non-seminomatous tumors (Honecker et al., 2006).

\section{Regulation of pluripotency}

Embryonic development is controlled by highly orchestrated patterns of gene expression (both temporal and tissue specific). It

\footnotetext{
Abbreviations used in this paper: AIS, androgen insensitivity syndrome; CIS, carcinoma in situ; EC, embryonal carcinoma; ES cell, embryonic stem cell; GA, gestational age; GB, gonadoblastoma; GCC, cerm cell cancer; H3K4Me3, H3 lysine 4 trimethylation; H3K4me1, H3 lysine 4 monomethylation; H3K27Me3, H3 lysine 27 trimethylation; H3K27Ac, H3 lysine 27 acetylase; LINE, long interspersed nucleotide element; PGC, primordial germ cell; SINE, short interspersed nucleotide element; 5mC, 5-methylcytosine; 5hmC, 5-hydroxymethylcytosine.
}

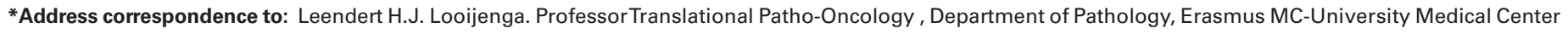
Rotterdam, Building Be (Josephine Nefkens Institute), Room 432 (laboratory room 435), P.O. Box 2040, 3000 CA Rotterdam, The Netherlands.

E-mail: I.looijenga@erasmusmc.nl-Tel/Fax: (31)-10-7044329/65
}

\#Note: Both authors contributed equally to the work

Final, author-corrected PDF published online: 5 June 2013.

ISSN: Online 1696-3547, Print 0214-6282 
is essential to understand these networks in order to gain insight into disturbed development, including cancer. A number of genes are known to play critical roles in establishing and maintaining pluripotency, including OCT3/4, NANOG, SOX2 (Chambers et al., 2003, Chan et al., 2011, Scholer et al., 1990, Young, 2011). As such they are candidates for involvement in GCC development. Indeed, OCT3/4 has been shown to be an important diagnostic marker for the different histological elements of GCCs, including the precursor lesions (Looijenga et al., 2003). Expression of SOX2 is seen in non-seminomas, especially and consistently in embryonal carcinomas, and more heterogeneously in the other components, whereas expression of a related gene, SOX17, is present in normal germ cells, CIS/GB and seminomas (de Jong et al., 2008, Korkola et al., 2005).

\section{Genetics and epigenetics in germ cell cancer}

Although much knowledge has been gained over the last decades, the exact role of the various risk factors involved in development of GCC is still unclear. Several genetic loci have been linked to increased risk of GCC (Rapley et al., 2009), and the familial predisposition (i.e., increased risk of brothers and sons) (Coffey et al., 2007) supports a significant genetic component in the pathogenesis of this type of cancer. So far, somatic mutations are rare in GCC (Bignell et al., 2006), with a few notable exceptions such as KIT and KRAS2 (Biermann et al., 2007, Hersmus et al., 2012, Mclntyre et al., 2008). It is therefore likely that epigenetic factors are involved in GCC development as well. This is not unexpected as a clear role for epigenetic regulatory processes exist in both the mechanisms of initiating and protecting pluripotency of embryonic stem cells as well as in maintaining the identity of differentiated cell types (Hawkins et al., 2011). Deregulation of this process may alter chromosomal stability, specifying properties of stem cells, self-renewal and the potential to differentiate, leading to initiation and/or progression of cancer. Disrupted epigenetic regulation might therefore be one of the underlying factors in the origin and biology of GCC. As such, epigenetic alterations could be candidates for specific diagnostic and prognostic markers. This review gives an overview of the rapidly growing field of understanding the impact of epigenetics in normal and disrupted development, specifically in the pathogenesis of GCC.

\section{Gonadal development: an introduction}

PGC are the progenitor cells of gametogenesis in later life, first recognized at day E6.5 in mice and 5-6 weeks gestational age (GA) in humans (McLaren, 2003). These PGC are characterized by their alkaline phosphatase reactivity, which is used as a specific marker (Millan and Fishman, 1995). Immediately prior to this, pre-PGC begin to express BLIMP1 mRNA and protein, which maintains the pluripotent state (Ohinata et al., 2005). During migration PGC proliferate extensively. Once they reach the genital ridge (around E9-10 in mice and 6-8 weeks GA in human, then called gonocytes), they are under the influence of the sex determination process of the bipotential gonad, under control of SOX9 and FOXL2, amongst others (Morais da Silva et al., 1996, Uhlenhaut and Treier, 2006), into either testis or ovary. This determines germ cell fate towards either the male or female direction. Male germ cells continue to proliferate until they differentiate to pre-spermatogonia, that then enter mitotic arrest.

\section{Epigenetics and (germ cell) development}

Epigenetics is commonly defined as inheritable changes affecting gene regulation that are not due to alterations in primary DNA sequence. The epigenome is highly dynamic, and can change depending on cell type and developmental stage within a single organism. The epigenetic processes work together to establish and maintain both global as local chromatin states e.g. open or condensed which determines gene expression (see Fig. 1 for an overview (Baylin and Jones, 2011)). Epigenetic modifications are relatively stable in somatic cells. In germ cells, however, the epigenome is reprogrammed on a genome-wide level. By E12.5/10 weeks GA most DNA methylation is lost (Reik and Walter, 2001) and de novo methylation is initiated in males at E14.5, leading to highly methylated mature gametes. This allows re-establishment of parental imprints in germ cells, the erasure of epimutations, and the generation of toti- or multipotent cells (Godmann et al.,

\section{Epigenetic marks}

Gene Expression

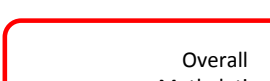

Overall
Methylation

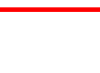

CpG isla
Methylation

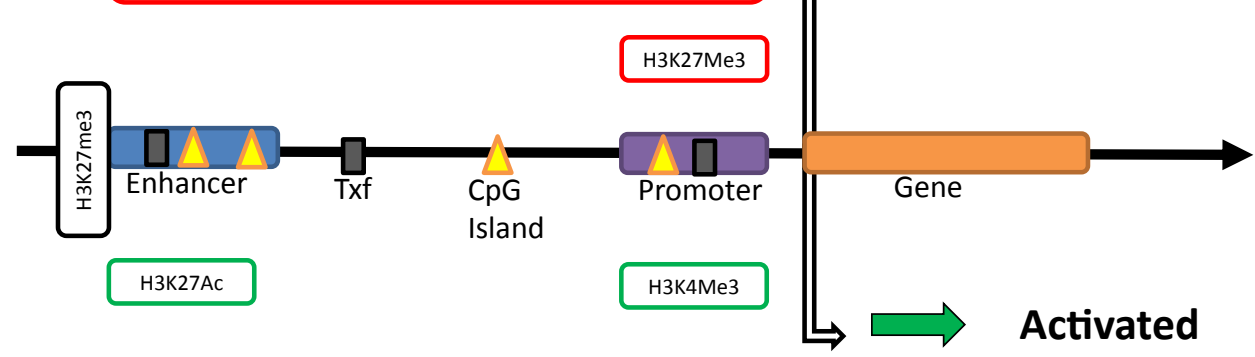

Fig. 1. Schematic representation of the role of epigenetic changes in regulating gene expression, controlled by DNA methylation and histone modification. This will determine whether a gene is susceptible for transcription or not, related to the presence of appropriate transcription factors. In general, DNA methylation (indicated in the red box) is associated with gene silencing. It can occur at enhancer and promoter sites, as well as at CpG islands/ shores. In this scheme the enhancer site is located in front of the gene, but can be located several Mb away (up-or downstream) from the gene. Histone modifications occur at enhancer or promoter sites and can be either activating or silencing (indicated in red and green box, respectively). In general, $\mathrm{H} 3 \mathrm{~K} 4 \mathrm{Me} 3$ is active, whereas $H 3 K 27 M e 3$ in the promoter region is inactive or silenced. The presence of both represents a bivalent state. A high H3K27Ac mark at an enhancer site is indicative for an active enhancer state. The presence of H3K27me3 together with the absence of H3K27ac will poise the enhancer for activation or repression at a later stage in development. 
2009, Hajkova et al., 2002, Seki et al., 2007). Genomic imprinting results in the silencing of one of the parental alleles in a subset of genes, and is different between different tissues and cell types (Prickett and Oakey, 2012). In addition, epigenetic modifications play essential roles in transmitting transcriptional memory; i.e. the phenomenon that epigenetic marks can be inherited across more than one generation (Jones and Liang, 2009). Our knowledge of the epigenome has increased enormously due to next-generation sequencing techniques for mapping DNA methylation and chromatin modifications. A number of relevant issues in this context will be presented in the next paragraph.

\section{Epigenetic memory and inheritance}

Epigenetic modifications play essential roles in transmitting transcriptional memory to daughter cells following mitosis (Jones and Liang, 2009). In rare cases GCC development depends on known genetic alterations, however, abnormal cellular memory or epigenetic changes that lead to aberrant gene expression patterns are also critical for tumor initiation and progression (Esteller, 2008).

In general, epigenetic marks are cleared and re-established with each generation i.e. reprogramming in $P G C$ to ensure the totipotency of cells of the early embryo. However, the environment can stably influence epigenetic marks, which suggest that transgenerational epigenetic inheritance exists. The first evidence that epigenetic marks could indeed be inherited across more than one generation involved transgenes (Allen et al., 1990, Sapienza et al., 1987, Swain et al., 1987). More recently, Lang-Mladek et al., showed in plants that, after extreme temperature or UV-B stress, a silent transgene and several transposable elements were activated, and these changes were heritable for two generations (Lang-Mladek et al., 2010). This suggests that some epigenetic marks may avoid erasure during early development, including the germ line. Some repetitive elements show incomplete erasure, which may be essential for chromosome stability and for preventing activation of transposons to reduce the risk of germline mutations. It was shown in mice, that partial deficiency of Apobec1 cytidine deaminase in the maternal germ-line led to suppression of teratomas in both partially and fully deficient males, and significantly reduced teratoma risk in a transgenerational manner among wildtype offspring. These heritable epigenetic changes persisted for multiple generations, and could be fully reversed (Nelson et al., 2012). Aberrant epigenetic reprogramming in the germ line would cause the inheritance of epimutations, that may have consequences for human diseases (Hajkova et al., 2002, Popp et al., 2010). The same is true for histone modifications. It was initially thought that all histones were cleared and replaced by protamines (Oliva et al., 1987), however in sperm, part of the haploid genome remains packed into nucleosomes. These histones are enriched at gene promoters important for development, as well as imprinted genes (Hammoud et al., 2009). This provides these genomic loci with the ability to convey instructive epigenetic information to the zygote. Indeed, genome-wide analysis in fertile and non-fertile men showed that there are moderate differences at these loci, which may have a cumulatively detrimental effect on fecundity (Hammoud et al., 2011).

Recently the focus of epigenetic inheritance research has moved to the role of small RNAs e.g. miRNAs, endo-siRNAs and piRNAs. These are present in both sperm and oocytes, and are known to be involved in gene silencing (Ashe et al., 2012, Grandjean and
Rassoulzadegan, 2009, Lee et al., 2012, Shirayama et al., 2012, Watanabe et al., 2006). Interestingly, small RNAs are associated with the production of a mobile signal that can travel between cells and over long distances in plants and nematodes (Melnyk et al., 2011). Three recent papers suggest that piRNAs can trigger a multigenerational epigenetic memory in the germline of $C$. elegans, and that it might be involved in scanning the germline transcriptome for foreign sequences, while endogenous germ-line-expressed genes are actively protected from piRNA-induced silencing (Ashe et al., 2012, Lee et al., 2012, Shirayama et al., 2012). Although there could be a role in GCC development and inheritance via aberrant piRNA regulation, the mechanisms and biology remain poorly understood. The role of RNAs in transgenerational inheritance is extensively reviewed elsewhere (Daxinger and Whitelaw, 2012, Jones and Liang, 2009, Rassoulzadegan and Cuzin, 2010).

\section{DNA methylation development and cancer}

Epigenetics includes DNA methylation. This refers to the fact that DNA can be modified by the addition of a methyl group to cytosine residues, generating 5 -methylcytosine $(5 \mathrm{mC})$. Three genes are known to be involved in the methylation of cytosine residues. DNMT3A and DNMT3B are de novo DNA methyltransferases, and together with the maintenance methyltransferase DNMT1 are necessary for DNA methylation essential for embryonic development ( $\mathrm{Li}$ etal., 1992, Okano et al., 1999). Other functions for these enzymes have been reported recently, but will not be discussed here (Chen et al., 2012). In germ cells, DNMT3L is expressed in testes at the stage of de novo methylation, and interacts with DNMT3A and $\mathrm{B}$ (Bourc'his and Bestor, 2004). Recently, DNMT3L was described as a novel Embryonal Carcinoma (EC) marker, shown to be essential for growth of these cells (Minami et al., 2010). DNA methylation was primarily thought to occur at $\mathrm{CpG}$ islands (Sasaki and Matsui, 2008), but recent studies based on whole genome analyses have shown the existence of so-called CpG "shores". This refers to methylation areas located adjacent to $\mathrm{CpG}$ islands in regions of less dense CpG dinucleotides (Doi et al., 2009). In addition, almost $25 \%$ of methylation in Embryonic Stem (ES) cells is found outside of CG motifs, being lost upon differentiation (Lister et al., 2009). Hypermethylation of $C p G$ islands (strongly associated with gene promoters), and associated gene silencing by transcriptional repression due to inhibition of transcription factor binding is the most extensively studied epigenetic mechanism in cancers (Baylin and Jones, 2011, Jones, 2012, Park et al., 2011) including GCC (Ellinger et al., 2009, Honorio et al., 2003, Manton et al., 2005). DNA hypomethylation is generally associated with gene activation. Therefore, DNA methylation is a critical part of the control of gene expression, and as such regulatory of differentiation. It is a key part of embryonic development, chromosome stability and genomic imprinting (Jones, 2012). A complete lack of methylation can only occur in ES cells, but has not been seen in cancer cells (Chen et al., 2007, Tsumura et al., 2006). Of specific interest is the fact that imprinting-free ES cells can result in malignant transformation, by conferring cellular immortality (Holm et al., 2005), including a seminomatous-like cancer.

During epigenetic reprogramming of germ cells, the genome becomes demethylated, and reprogramming by de novo methylation will be initiated during later stages of development. Here, TET1 was found to have an important role, as it catalyzes the oxidation 
of $5 \mathrm{mC}$ into 5-hydroxymethylcytosine $(5 \mathrm{hmC})$ and therefore might play a role in the removal of $5 \mathrm{mC}$. Indeed, repression of TET1 correlated with a reduction in $5 \mathrm{hmC}$ levels (Tahiliani et al., 2009), and high level of Tet1 expression is detected in PGC (Hajkova et al., 2010). The role of TET1 and $5 \mathrm{hmC}$ in the epigenome is extensively reviewed elsewhere (Branco et al., 2012).

\section{Origin of GCC and link to methylation}

All GCC originate from a common precursor, the PGC/gonocyte (Oosterhuis and Looijenga, 2005), this is in line with findings on Alkaline phosphatase (Stoop et al., 2011). It has been shown that global methylation status of GCC subtypes differ according to the time point of their developmental arrest; more differentiated cells showed a higher degree of methylation (Okamoto and Kawakami, 2007, Smiraglia et al., 2002, Wermann et al., 2010). It is also known that CIS/GB cells show very little DNA methylation(Netto et al., 2008, Smiraglia et al., 2002, Wermann et al., 2010). Seminomatous GCC subtypes showed more global hypomethylation and almost no $\mathrm{CpG}$ island methylation, whereas non-seminomas showed more methylated DNA, both globally and at CpG islands. A targeted analysis of 15 promoter regions confirmed that there are differences in methylation profiles between the different GCC (Brait et al., 2012). Moreover, Ellinger et al., showed that detection of hypermethylated cell - free circulating DNA is feasible in most patients with GCC who undergo orchiectomy (Ellinger et al., 2009). The diagnostic information received from cell - free methylated DNA by testing multiple gene sites seemed to be superior to that of conventional markers. Fig. 2 shows the assessment of global $5 \mathrm{mC}$ methylation, DNMT3L mediated methylation and maintenance methyl transferase DNMT1 by immunohistochemistry for embryonic testis, different histological elements of GCC and their precursors. This confirms the presence of different methylation profiles in the GCC subtypes, with the more differentiated being more methylated, associated with different methyltransferases.

\section{$X$ inactivation and XIST expression in GCC}

Acquired numerical chromosomal changes in $X$ chromosomes are commonly observed in GCC (Oosterhuis et al., 1997). Inactivation of one of the $X$ chromosomes in female mammalian cells is necessary to balance the increased dosage of $X$-linked genes compared with male cells (Ballabio and Willard, 1992). This process is initiated by the RNA gene XIST, expressed exclusively by the inactive form of the $X$ chromosome, and results in hypermethylation of specific sites of genes to be silenced. In males, XIST is only detectable in germ cells of the normal male testis (Salido et al., 1992). In GCC XIST is expressed only in tumors derived from the germ cell lineage with supernumerical $X$ chromosomes: seminomas, nonseminomas, and spermatocytic seminomas. Although low XIST expression is present in testicular parenchyma with spermatogenesis, it is expressed at a higher level in parenchyma with CIS (Looijenga et al., 1997).

Kawakami et al., showed that AR, FMR1 and GPC3 (all Xlinked genes) remained unmethylated in both seminomas and non-seminomas with XIST expression (Kawakami et al., 2004), normally methylated in inactive $X$ chromosomes. Identification of unmethylated XIST DNA fragments in male plasma might serve as a diagnostic marker for GCC, although these findings need to be confirmed in independent studies.

\section{Repetitive elements and germ cell cancers}

A significant fraction of the genome (approximately $42 \%$ ) is composed of repetitive elements (Lander et al., 2001). Two major classes can be identified; long interspersed nucleotide elements (LINEs) and short interspersed nucleotide elements (SINEs). LINE1 and SINEs of the Alu family are the most prominent elements, and both are highly methylated in normal tissues (Kazazian, 2004, Lander et al., 2001). Ushida et al., showed that both LINE1 and Alu repeats are unmethylated in seminomas, whereas only LINE1 is unmethylated in non-seminomas and EC (Ushida et al., 2011). Thus the degree of demethylation of the repetitive elements is more pronounced in seminomas compared to non-seminomas, and GCC were more demethylated compared to cancers originating from somatic tissues (Ushida et al., 2011).

\section{Cisplatin sensitivity of germ cell cancers}

Another factor that distinguishes seminomas and non-seminomas compared to other solid cancers is their overall responsiveness to cisplatin, a chemotherapeutic agent which binds to DNA, inducing crosslinks, which ultimately triggers apoptosis (Rosenberg et al., 1965). Seminomas are usually sensitive to chemotherapy with cisplatin, whereas the response of non-seminomas differ according to their histology. Teratomas, which are the most differentiated GCC, show the highest degree of methylation and are cisplatin resistant (Krege et al., 2008, Mayer et al., 2003). In addition, cisplatin-resistant GCC showed different overall methylation profiles than non - resistant forms (Koul et al., 2004, Netto et al., 2008, Wermann et al., 2010). Hypermethylation might therefore be a diagnostic marker as well as a predictive marker of treatment response. Exposure of TCam-2, a highly cisplatin resistant seminoma cell line, to the demethylation agent 5-aza-cytidine resulted in an increased sensitivity to cisplatin. Subsequent analysis of $\mathrm{CpG}$ island methylation showed that there were different methylation profiles in the treated and non-treated cells. For example, the promoter region of the CFLAR (c-FLIP) gene was hypermethylated in the treated cell line (Wermann et al., 2010). CFLAR has an important role in regulation of apoptosis via the caspase pathway and therefore could be a therapeutic target (Yang, 2008), something that needs further evaluation. In addition, it has been shown that CFLAR can identify GCC patients with cisplatin resistance, based on genomewide expression analysis (Sugimura et al., 2004). Induction of cFLIP has been reported in EC cell lines, as expected this results in resistance to cisplatin (Spierings et al., 2004).

\section{Histone modifications}

Histones and associated chromatin proteins control the accessibility of genes and genomic elements. DNA is folded into nucleosomes; histone octameres consisting of two copies of each of the four histone proteins $\mathrm{H} 2 \mathrm{~A}, \mathrm{H} 2 \mathrm{~B}, \mathrm{H} 3$ and $\mathrm{H} 4$, wrapped with approximately $147 \mathrm{bp}$ of DNA. A wide range of histone modifications, including methylation, acetylation and phosphorylation of specific amino acid residues, have been identified (Ernst and Kellis, 2010). These are often associated with genomic regions with regulatory potential, and it has been proposed that different combinations of histone modifications can be linked to specific types of functional elements (Strahl and Allis, 2000).

Technological advances have allowed the mapping of diverse 
Epigenetics in Germ Cell Cancer

histone modifications in a large number of cell types (Doege et al., 2012, Ferguson et al., 2012, Shahhoseini et al., 2010). In this context a number of relevant DNA segments must be recognized, which will be discussed in more detail in the next paragraphs.

\section{Promoters}

Specific promoter-associated chromatin signatures involved in regulating proliferation have been identified. In general, $\mathrm{H} 3$ lysine 4 trimethylation ( $\mathrm{H} 3 \mathrm{~K} 4 \mathrm{Me} 3$ ) is associated with active regions, whereas $\mathrm{H} 3$ lysine 27 trimethylation ( $\mathrm{H} 3 \mathrm{~K} 27 \mathrm{Me} 3$ ) is associated with inactive or silenced loci. The presence of both represents a bivalent state, and has been identified in cells with pluripotent potential such as ES cells (Azuara et al., 2006, Bernstein et al., 2006). Hawkins et
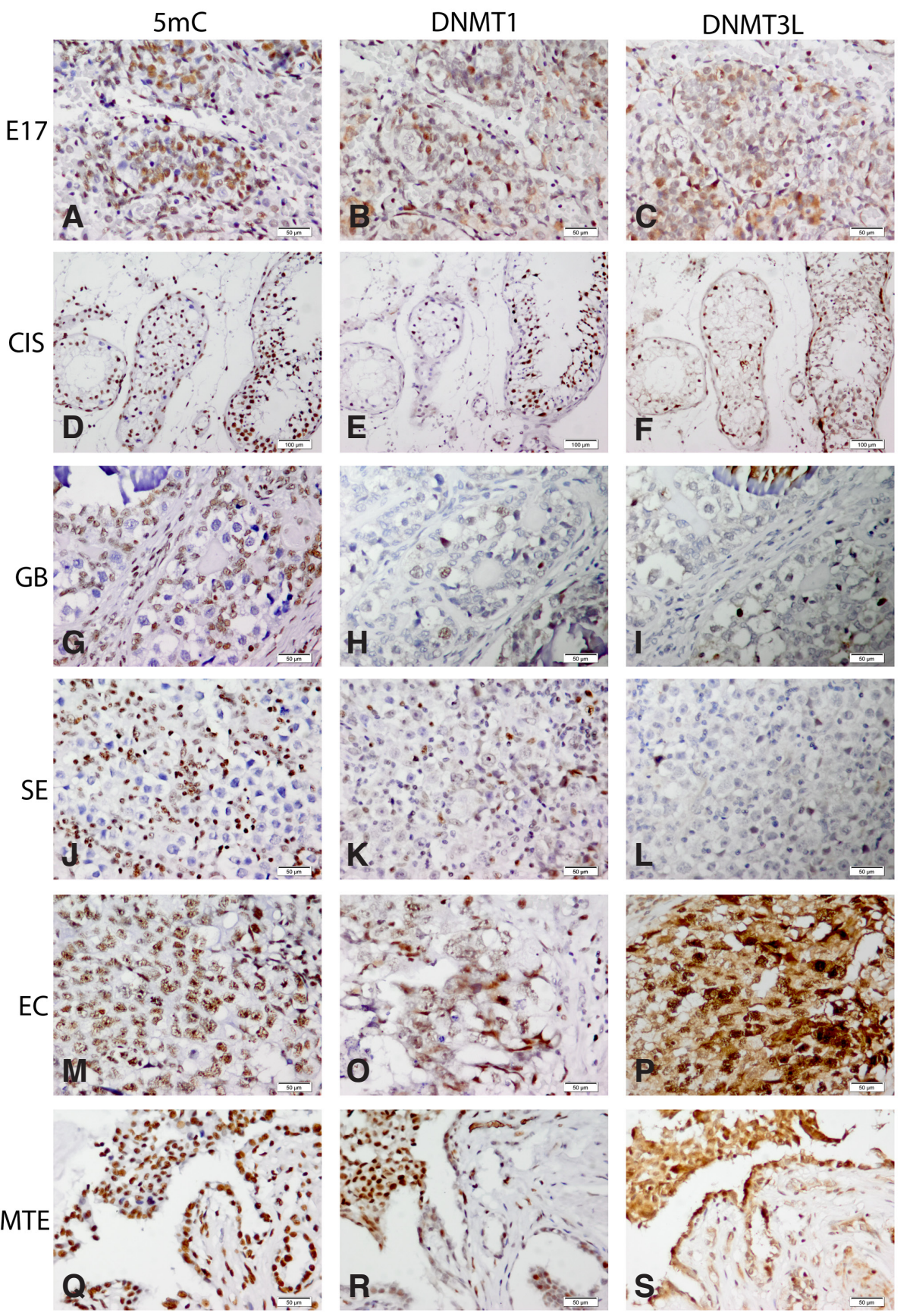

al., showed that modifications at promoters remain largely invariant during differentiation, except at a small number of promoters where a dynamic switch between acetylation (H3K27Ac) and methylation at H3K27 marks the transition between activation and silencing of gene expression. This suggests a hierarchy in cell fate commitment over most differentially expressed genes (Hawkins et al., 2011).

\section{Enhancers}

Enhancers are defined as sequences, often outside the gene body, that regulate when and where a gene is expressed. Several histone marks have been associated with enhancers, including $\mathrm{H} 3 \mathrm{~K} 4 \mathrm{me} 1 / 2$ and H3K27ac/me3. The current model in human ES cells is that high $\mathrm{H} 3 \mathrm{~K} 27 \mathrm{Ac}$ is indicative for an active enhancer state.

Loss of $\mathrm{H} 3 \mathrm{~K} 27 \mathrm{Ac}$ and presence of $\mathrm{H} 3 \mathrm{~K} 27 \mathrm{Me} 3$ will poise the enhancer for activation or silencing during differentiation (Rada-Iglesias et al., 2011).

\section{Germ cell development and GCC}

PGC actively suppress somatic differentiation programs by epigenetic modifications, a mechanism which might also account for CIS and seminoma (Hayashi et al., 2007). In mice, PGC increase levels of H3K27me3 by E8.5E9.5, with levels reduced atE10.5-11 (Hajkova et al., 2008). Utx, an H3K27 demethylase, regulates efficient induction of pluripotency. In the absence of Utx, PGC showed aberrant, cell-autonomous germ cell development during their embryonic maturation in vivo, as well as aberrant epigenetic reprogramming (Mansour et al., 2012). CIS cells showed low levels of the repressive histone modifications H3K9me2 and H3K27me3, but high levels of activating marks $\mathrm{H} 3 \mathrm{~K} 9 \mathrm{Ac}, \mathrm{H} 3 \mathrm{~K} 4 \mathrm{me}$ and H2A.Z (Almstrup et al., 2010). This permissive chromatin structure is in accordance with the high levels of RNA polymerase II activity and proliferation that were observed in CIS cells. Epigenetic patterns similar to that of CIS cells

Fig. 2. Immunohistochemical staining for $5 \mathrm{mC}$ (left column), DNMT1 (middle column) and DNMT3L (right column) on an embryonic testis, at the $17^{\text {th }}$ week of development (E17) (first lane), the different GCC and their precursor lesions $\left(2^{\text {nd }}\right.$ $6^{\text {th }}$ lane). In the embryonic testis the germ cells are negative for $5 \mathrm{mC}$ (A), negative to weak positive for DNMT1 (B) and DNMT3L; Carcinomain situ cells are negative for $5 \mathrm{mC}$ (D), positive for DNMT1 (E) and positive for DNMT3L (F); Gonadoblastoma stains negative for $5 \mathrm{mC}(\mathbf{G}), D N M T 3 L(\mathbf{I})$, and negative to weak positive forDNMT1(H); Seminoma/Dysgerminoma (SE/DG) stain negative for $5 \mathrm{mC}$ (J), DNMT1 (K) and DNMT3L (L); Embryonal Carcinoma (EC) shows a heterogeneous pattern for both $5 \mathrm{mC}$ (M), DNMT1 (0) and positive for DNMT3L (P); Mature Teratoma (MTE) stains positive for all markers $(\mathbf{Q}, \mathbf{R}, \mathbf{S})$. All slides are counterstained with hematoxylin. Magnification 200x for all but 100x for CIS. 
were observed in human gonocytes present within sex cords in foetal testes and corresponds to migrating primordial germ cell in mice (Almstrup et al., 2010). CIS cells therefore have a permissive and foetal-like chromatin structure, which is associated with high transcriptional and proliferative activity.

Ohinata et al., showed that Blimp1, a known transcriptional repressor, has a critical role in the development of the mouse germ cell lineage, as disruption of Blimp1 causes a block early in the process of PGC formation. Blimp1-deficient mutant embryos form a tight cluster of about 20 PGC-like cells, which fail to show the characteristic migration, proliferation and consistent repression of homeobox genes that normally accompany specification of PGC (Ohinata et al., 2005). BLIMP1 and PRMT5 were expressed, and dimethylation of histones $\mathrm{H} 2 \mathrm{~A}$ and $\mathrm{H} 4$ was detected in human male gonocytes at weeks 12-19 of gestation, indicating a role of this mechanism in human fetal germ cell development (Eckert et al., 2008). In addition, this study also showed that BLIMP1/ PRMT5 and histone $\mathrm{H} 2 \mathrm{~A}$ and $\mathrm{H} 4$ arginine 3 dimethylation are present in CIS and most seminomas, and less in EC and other nonseminomas. Recently, Schuster-Böckler and Lehner showed that chromatin organization has a major influence on regional mutation rates (Schuster-Bockler and Lehner, 2012). Mutation rates were positively correlated with heterochromatin related marks, of which histone modification H3K9Me3 was most important, and accounted for more than $40 \%$ of the somatic mutation variants (Schuster-Bockler and Lehner, 2012). The open chromatin in regions involved in embryonic development showed a negative association, which is in line with the fact that mutations are rarely found in GCC and the idea that the germ line is protected for mutations (immortal strand). In fact it points towards a regulatory role for histone modifications and chromatin structure on germline mutation rates, as the chromatin organization in the germline is substantially different to that in somatic cells (Hajkova et al., 2002).

\section{Histone modification in GCC cell lines}

Relatively little is known about histone modifications involved in GCC. We therefore initiated a study to explore the epigenetic differences between GCC subtypes, using the cell lines TCam-2 and NCCIT as representatives of seminomas and non-seminomas respectively (van der Zwan, in preparation). As depicted in Fig. 3 , our initial analysis matched the classification of the cell-lines. SOX17 was strongly enriched for H3K4me1 and H3K27ac in TCam-2 compared to NCCIT cells, whereas the opposite pattern was observed for SOX2. Additional analysis of the epigenetic differences between the two cell lines, along with the extension of these studies to cancer tissues, will contribute to our understanding of the role of histone modifications in GCC.

\section{Environmental factors in the pathogenesis of GCC}

Environmental factors can influence epigenetic processes, and may therefore be related to cancer development (Brait et al., 2009, Lang-Mladek et al., 2010). There are indications that endogenous factors such as the hormonal balance between estrogens and androgens might play a role (Godmann et al., 2009). It is known that diethylstilbestrol (DES), used widely to reduce the risk of abortions, led to a higher risk of hypospadias, cryptorchidism and poor semen quality in male offspring (Sharpe and Skakkebaek, 1993). The use of DES was abandoned after it was associated with cervical cancer (Herbst et al., 1971). It was shown that DES exposure in the third generation still leads to an increased risk of hypospadias(Brouwers et al., 2006). The risk of GCC development in this patient group is controversial, and a slightly increased risk has been reported (Strohsnitter et al., 2001). The transgenerational effect of DES is

A

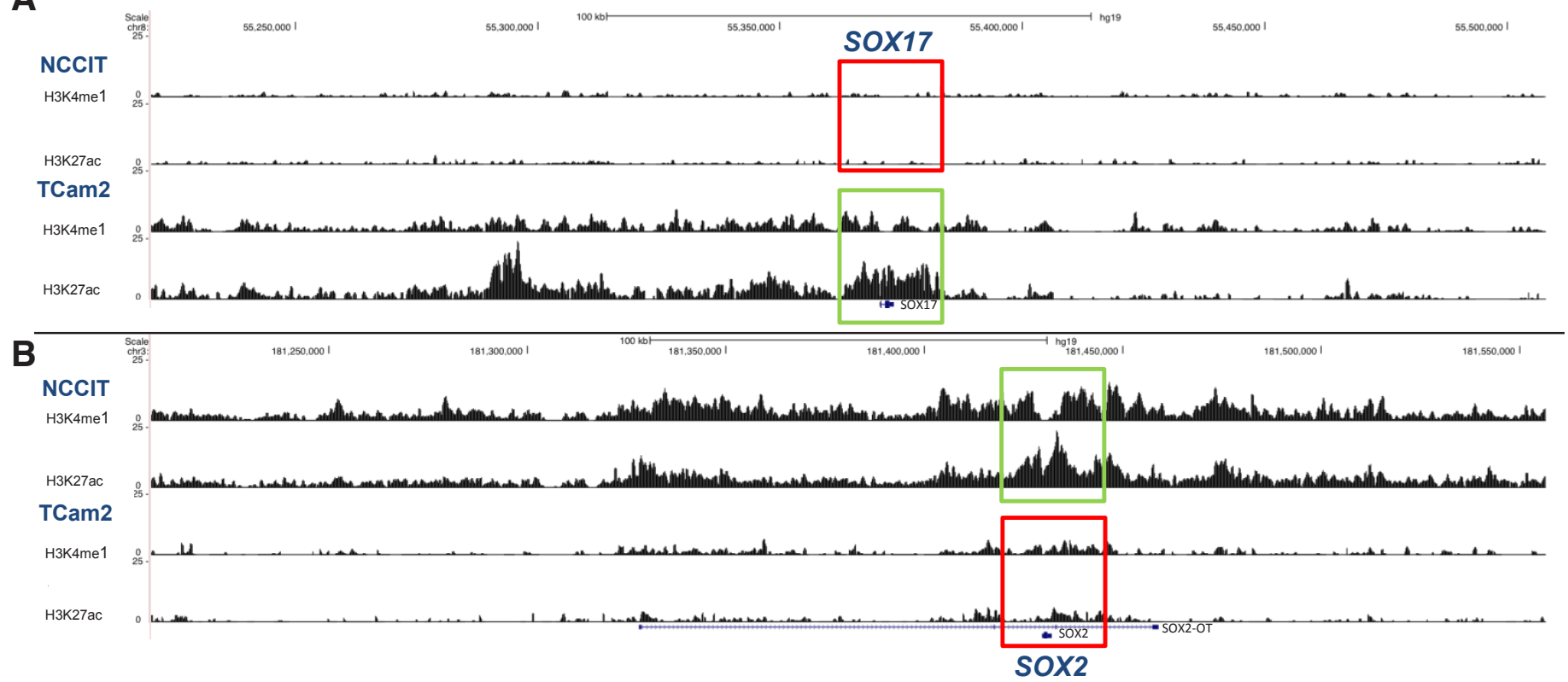

Fig. 3. Display of H3K4me1 and H3K27ac tracks for both NCCIT and TCam-2. The red box indicates a repressive state and the green box an active state. Figure derived from the UCSC Genome Browser. (A) Genomic region around the SOX17 gene, showing strong enrichment for both H3K4me 1 and H3K27ac in TCam-2 (representative of seminoma) vs NCCIT (representative of Non-seminoma) cells. Enrichment outside this region is likely indicating regulatory elements such as enhancers. SOX17 is used as a diagnostic marker for differentiating seminoma from non-seminoma. (B) Genomic region around the SOX2 gene, showing strong enrichment for both H3K4me1 and H3K27ac in TCam-2 vs NCCIT cells. SOX2 is used as a diagnostic marker for differentiating non-seminoma from seminoma. 
however suggestive for heritable epigenetic alterations. In addition, exogenous estrogen may interrupt the maturation of primitive germ cells by reducing the secretion of Anti- Müllerian hormone from the Sertoli cells (Longnecker et al., 2002). Hormonal factors can also induce methylation of promoter regions of certain genes (Kutanzi et al., 2010).

Major geographic differences in incidence are consistent with environmental influences. Increased use of endocrine disruptors has been suggested to be one of the environmental factors responsible for the increasing incidence of testicular GCC in testicular dysgenesis syndrome (TDS) (Skakkebaek et al., 2001). A meta-analysis confirmed the link between estrogen exposure and GCC (Storgaard et al., 2006). Developmental disturbances of the micro-environment could result in inadequate maturation of the germ cells. This may result in a foetal epigenetic profile which, upon hormone stimulation during puberty, leads to an aberrant induction of transcription and proliferation, ultimately leading to GCC later in life (Almstrup et al., 2010).

In this context, patients with Disorders of Sex Development (DSD) form an intriguing model to study the impact of intrinsic and environmental factors on normal and abnormal gonadal development. Indeed the diagnosis of $46, X Y$ and chromosomal DSD is a risk factor for the development of GCC, with higher risk associated with an earlier block in differentiation. Other risk factors include anatomical position of the gonad, the presence of Y-chromosomal material (GBY region), genetic and epigenetic anomalies (Cools et al., 2006, Cools et al., 2011).

It has been shown that seminomas are more often found in abdominal testes compared to scrotal testes (Ogunbiyi et al., 1996). This might also explain the occurrence of dysgerminomas in the ovary and dysgenetic gonads, which are both located in the abdomen. Indeed, seminoma and dysgerminomas are similar in morphology and gene expression profile, and therefore might have the same epigenetic profiles (Dietl et al., 1993, Looijenga et al., 2006, Susnerwala etal., 1991). Bens et al., showed that HOXA5 represents a candidate gene of androgen-mediated promoter methylation, by studying patients with Complete or Partial Androgen Insensitivity Syndrome (CAIS and PAIS respectively) (Bens et al., 2011). HOXA5 was significantly hypermethylated in CAIS patients compared to normal male controls, whereas PAIS patients could be both hyper- or hypo methylated. This suggests that HOXA5 promoter methylation is at least partly controlled by androgen receptor activity and could possibly explain PAIS heterogeneity. In addition, TSPY was found to be a repressor for androgen signaling due to entrapping of the cytosolic androgen receptor, even in the presence of androgens. Androgen treatment stimulated cell proliferation and TSPY expression was found to be reduced in more malignant GCC (Akimoto et al., 2010). Together, these results underline the theory that the androgen-estrogen balance is important in the etiology of GCC, in both AIS patients as well as 'healthy' men.

\section{Perspectives and concluding remarks}

Next generation sequencing has made it possible to study epigenetic processes in a genome-wide matter. Mapping and integration of these data with information from genetic and protein experiments will lead to a broader knowledge of cancer initiation and progression. Fig. 4 shows a pathogenetic model for GCC based on the different aspects discussed in this review. Genetic, epigenetic and environmental factors ('genviroment') play essential roles in normal gonadal development. After fertilization the PGC completely erase their biparental genomic imprint. Gonocytes undergo different epigenetic modifications (i.e. increased methylation and more condensed chromatin structure) during their differentiation along the male (testis) or female (ovary) pathway. The process of testis formation is referred as 'testicularization' of the gonad. The microenvironment of the PGC is essential for physiological maturation, and disruption of this process may lead to delayed maturation and possibly malignant transformation. In this respect, studies of DSD patients have increased our knowledge. Genetic factors, epigenetic aberrant reprogramming end/or environmental factors, referred to genvironmental parameters, can block the PGC in a fetal-like state, allowing proliferation. This block in maturation of the PGCs or gonocytes can therefore initiate a pathogenetic pathway, leading to the precursor lesions GB or CIS that can eventually progress to

\section{Genvironmental interactive pathways}

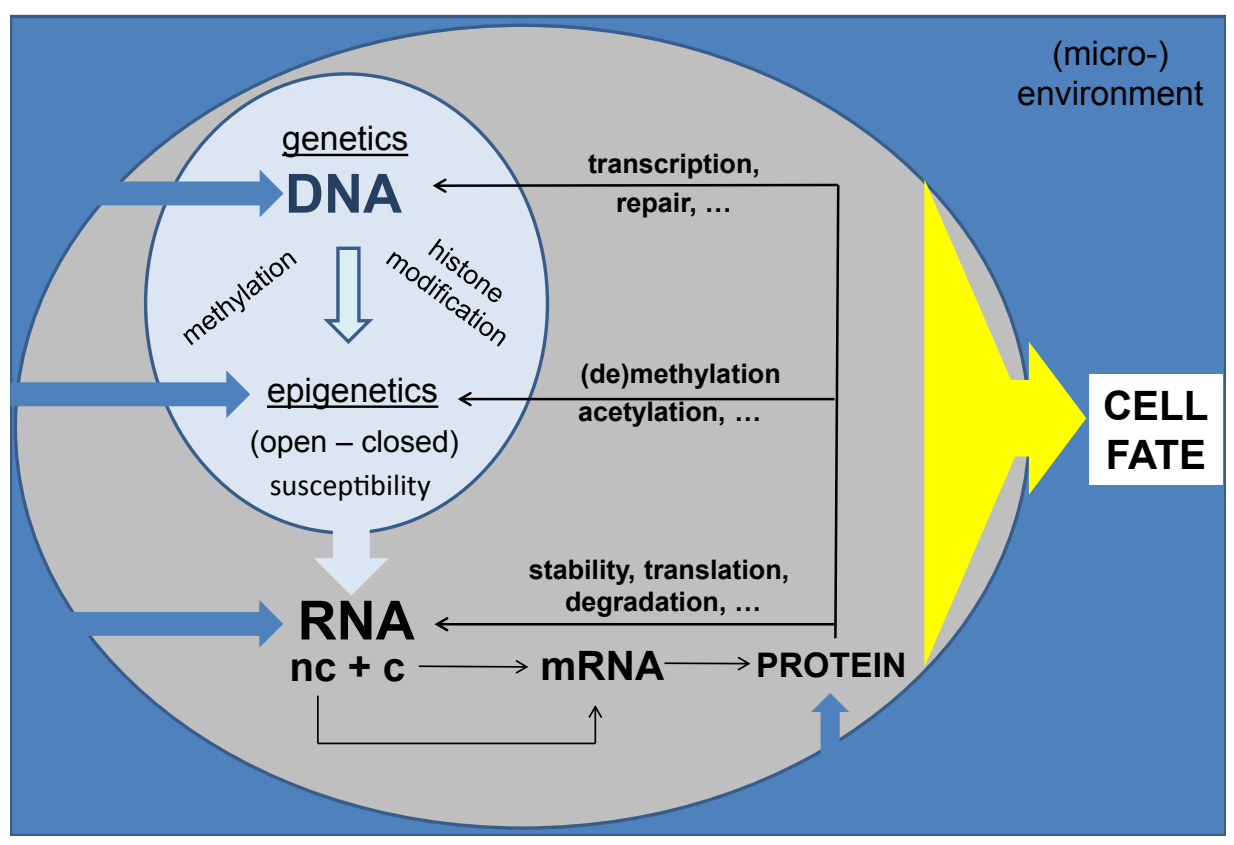

Fig. 4. Final cell fate depends on interaction of a large number of parameters, including genetics, epigenetics, transcription and translation, in interaction with the (micro)environment. This is referred to as Genvironment. At the genetic level, DNA functionality can be influenced by various mechanisms, for instance transcription or repair. Epigenetics (1.e. DNA methylation and histone modifications) will determine chromatin structure, and as such susceptibility of the genome for transcription. The process of gene transcription and translation is dependent on these parameters, the presence of appropriate transcription factors, as well as stability, translation and degradation of enzymes, RNA and protein. In fact, (micro)environmental factors can impact on all these levels. 
invasive GCC. Additional research may allow epigenetic profiles to identify risk groups, predict clinical outcomes and allow the development of targeted therapies in patients with high risk for development of GCC.

\section{Acknowledgements}

This work is supported by funding from the European Society for Pediatric Endocrinology Research Fellowship (YZ), Monash University (SW) and the Victorian Government's Operational Infrastructure Support Program (SW, FR).

\section{References}

AKIMOTO, C., UEDA, T., INOUE, K., YAMAOKA, I., SAKARI, M., OBARA, W., FUJIOKA, T., NAGAHARA, A., NONOMURA, N., TSUTSUMI, S. et al., (2010). Testis-specific protein on $Y$ chromosome (TSPY) represses the activity of the androgen receptor in androgen-dependent testicular germ-cell tumors. Proc Natl Acad Sci USA 107: 19891-19896.

ALLEN, N.D., NORRIS, M.L. and SURANI, M.A. (1990). Epigenetic control of transgene expression and imprinting by genotype-specific modifiers. Cell61: 853-861.

ALMSTRUP, K., NIELSEN, J.E., MLYNARSKA, O., JANSEN, M.T., JORGENSEN, A., SKAKKEBAEK, N.E. and RAJPERT-DE MEYTS, E. (2010). Carcinoma in situ testis displays permissive chromatin modifications similar to immature foetal germ cells. Br J Cancer 103: 1269-1276.

ASHE, A., SAPETSCHNIG, A., WEICK, E.M., MITCHELL, J., BAGIJN, M.P., CORDING, A.C., DOEBLEY, A.L., GOLDSTEIN, L.D., LEHRBACH, N.J., LE PEN, J. et al., (2012). piRNAs Can Trigger a Multigenerational Epigenetic Memory in the Germline of C. elegans. Cell. 150: 88-99.

AZUARA, V., PERRY, P., SAUER, S., SPIVAKOV, M., JORGENSEN, H.F., JOHN, R.M., GOUTI, M., CASANOVA, M., WARNES, G., MERKENSCHLAGER, M. et al., (2006). Chromatin signatures of pluripotent cell lines. Nat Cell Biol 8: 532-538.

BALLABIO, A. and WILLARD, H.F. (1992). Mammalian X-chromosome inactivation and the XIST gene. Curr Opin Genet Dev 2: 439-447.

BAYLIN, S.B. and JONES, P.A. (2011). A decade of exploring the cancer epigenome - biological and translational implications. Nat Rev Cancer 11: 726-734.

BENS, S., AMMERPOHL, O., MARTIN-SUBERO, J.I., APPARI, M., RICHTER, J., HIORT, O., WERNER, R., RIEPE, F.G., SIEBERT, R. and HOLTERHUS, P.M. (2011). Androgen receptor mutations are associated with altered epigenomic programming as evidenced by HOXA5 methylation. Sex Dev 5: 70-76.

BERNSTEIN, B.E., MIKKELSEN, T.S., XIE, X., KAMAL, M., HUEBERT, D.J., CUFF, J., FRY, B., MEISSNER, A., WERNIG, M., PLATH, K. et al., (2006). A bivalent chromatin structure marks key developmental genes in embryonic stem cells. Cell 125: 315-326.

BIERMANN, K., GOKE, F., NETTERSHEIM, D., ECKERT, D., ZHOU, H., KAHL, P., GASHAW, I., SCHORLE, H. and BUTTNER, R. (2007). c-KIT is frequently mutated in bilateral germ cell tumours and down-regulated during progression from intratubular germ cell neoplasia to seminoma. J Pathol 213: 311-318.

BIGNELL, G., SMITH, R., HUNTER, C., STEPHENS, P., DAVIES, H., GREENMAN, C., TEAGUE, J., BUTLER, A., EDKINS, S., STEVENS, C. et al., (2006). Sequence analysis of the protein kinase gene family in human testicular germ-cell tumors of adolescents and adults. Genes Chromosomes Cancer 45: 42-46.

BOURC'HIS, D. and BESTOR, T.H. (2004). Meiotic catastrophe and retrotransposon reactivation in male germ cells lacking Dnmt3L. Nature 431: 96-99.

BRAIT, M., FORD, J.G., PAPAIAHGARI, S., GARZA, M.A., LEE, J.I., LOYO, M., MALDONADO, L., BEGUM, S., MCCAFFREY, L., HOWERTON, M. et al., (2009). Association between lifestyle factors and $\mathrm{CpG}$ island methylation in a cancer-free population. Cancer Epidemiol Biomarkers Prev 18: 2984-2991.

BRAIT, M., MALDONADO, L., BEGUM, S., LOYO, M., WEHLE, D., TAVORA, F.F., LOOIJENGA, L.H., KOWALSKI, J., ZHANG, Z., ROSENBAUM, E. et al., (2012). DNA methylation profiles delineate epigenetic heterogeneity in seminoma and non-seminoma. Br J Cancer 106: 414-423.

BRANCO, M.R., FICZ, G. and REIK, W. (2012). Uncovering the role of 5-hydroxymethylcytosine in the epigenome. Nat Rev Genet 13: 7-13.

BROUWERS, M.M., FEITZ, W.F., ROELOFS, L.A., KIEMENEY, L.A., DE GIER, R.P. and ROELEVELD, N. (2006). Hypospadias: a transgenerational effect of diethylstilbestrol? Hum Reprod 21: 666-669.

CHAMBERS, I., COLBY, D., ROBERTSON, M., NICHOLS, J., LEE, S., TWEEDIE, S. and SMITH, A. (2003). Functional expression cloning of Nanog, a pluripotency sustaining factor in embryonic stem cells. Cell 113: 643-655.

CHAN, Y.S., YANG, L. and NG, H.H. (2011). Transcriptional regulatory networks in embryonic stem cells. Prog Drug Res 67: 239-252.

CHEN, C.C., WANG, K.Y. and SHEN, C.K. (2012). The Mammalian de novo DNA Methyltransferases Dnmt3a and Dnmt3b Are Also DNA5-Hydroxymethyl Cytosine Dehydroxymethylases. J Biol Chem. 87: 33116-33121.

CHEN, T., HEVI, S., GAY, F., TSUJIMOTO, N., HE, T., ZHANG, B., UEDA, Y. and LI, E. (2007). Complete inactivation of DNMT1 leads to mitotic catastrophe in human cancer cells. Nat Genet 39: 391-396.

COFFEY, J., HUDDART, R.A., ELLIOTT, F., SOHAIB, S.A., PARKER, E., DUDAKIA, D., PUGH, J.L., EASTON, D.F., BISHOP, D.T., STRATTON, M.R. et al., (2007). Testicular microlithiasis as a familial risk factor for testicular germ cell tumour. $\mathrm{Br}$ J Cancer 97: 1701-1706.

COOLS, M., DROP, S.L., WOLFFENBUTTEL, K.P., OOSTERHUIS, J.W. and LOOIJENGA, L.H. (2006). Germ cell tumors in the intersex gonad: old paths, new directions, moving frontiers. Endocr Rev 27: 468-484.

COOLS, M., PLESKACOVA, J., STOOP, H., HOEBEKE, P., VAN LAECKE, E., DROP, S.L., LEBL, J., OOSTERHUIS, J.W., LOOIJENGA, L.H., WOLFFENBUTTEL, K.P. et al., (2011). Gonadal Pathology and Tumor Risk in Relation to Clinical Characteristics in Patients with 45,X/46,XY Mosaicism. J Clin Endocrinol Metab 96: E1171-E1180.

DAXINGER, L. and WHITELAW, E. (2012). Understanding transgenerational epigenetic inheritance via the gametes in mammals. Nat Rev Genet 13: 153-162.

DE JONG, J., STOOP, H., GILLIS, A.J., VAN GURP, R.J., VAN DE GEIJN, G.J., BOER, M., HERSMUS, R., SAUNDERS, P.T., ANDERSON, R.A., OOSTERHUIS, J.W. et al., (2008). Differential expression of SOX17 and SOX2 in germ cells and stem cells has biological and clinical implications. $J$ Pathol 215: 21-30.

DIETL, J., HORNY, H.P., RUCK, P. and KAISERLING, E. (1993). Dysgerminoma of the ovary. An immunohistochemical study of tumor-infiltrating lymphoreticular cells and tumor cells. Cancer 71: 2562-2568.

DOEGE, C.A., INOUE, K., YAMASHITA, T., RHEE, D.B., TRAVIS, S., FUJITA, R., GUARNIERI, P., BHAGAT, G., VANTI, W.B., SHIH, A. et al., (2012). Early-stage epigenetic modification during somatic cell reprogramming by Parp1 and Tet2. Nature.

DOI, A., PARK, I.H., WEN, B., MURAKAMI, P., ARYEE, M.J., IRIZARRY, R., HERB, B., LADD-ACOSTA, C., RHO, J., LOEWER, S. et al., (2009). Differential methylation of tissue- and cancer-specific $\mathrm{CpG}$ island shores distinguishes human induced pluripotent stem cells, embryonic stem cells and fibroblasts. Nat Genet 41: 1350-1353.

ECKERT, D., BIERMANN, K., NETTERSHEIM, D., GILLIS, A.J., STEGER, K., JACK, H.M., MULLER, A.M., LOOIJENGA, L.H. and SCHORLE, H. (2008). Expression of BLIMP1/PRMT5 and concurrent histone $\mathrm{H} 2 \mathrm{~A} / \mathrm{H} 4$ arginine 3 dimethylation in fetal germ cells, CIS/IGCNU and germ cell tumors. BMC Dev Biol 8: 106.

ELLINGER, J., ALBERS, P., PERABO, F.G., MULLER, S.C., VON RUECKER, A. and BASTIAN, P.J. (2009). CpG island hypermethylation of cell-free circulating serum DNA in patients with testicular cancer. J Urol 182: 324-329.

ERNST, J. and KELLIS, M. (2010). Discovery and characterization of chromatin states for systematic annotation of the human genome. Nat Biotechnol 28: 817-825.

ESTELLER, M. (2008). Epigenetics in cancer. N Engl J Med 358: 1148-1159.

FERGUSON, J.P., CHO, J.H. and ZHAO, H. (2012). A new approach for the joint analysis of multiple ChIP-seq libraries with application to histone modification. Stat Appl Genet Mol Biol 11: Article 1.

GODMANN, M., LAMBROT, R. and KIMMINS, S. (2009). The dynamic epigenetic program in male germ cells: Its role in spermatogenesis, testis cancer, and its response to the environment. Microsc Res Tech 72: 603-619.

GRANDJEAN, V. and RASSOULZADEGAN, M. (2009). [Epigenetic inheritance of the sperm: an unexpected role of RNA] Epigenetique du spermatozoide: un role inattendu de l'ARN. Gynecol Obstet Fertil 37: 558-561.

HAJKOVA, P., ANCELIN, K., WALDMANN, T., LACOSTE, N., LANGE, U.C., CESARI, F., LEE, C., ALMOUZNI, G., SCHNEIDER, R. and SURANI, M.A. (2008). Chromatin dynamics during epigenetic reprogramming in the mouse germ line. Nature 452: 877-881. 
HAJKOVA, P., ERHARDT, S., LANE, N., HAAF, T., EL-MAARRI, O., REIK, W., WALTER, J. and SURANI, M.A. (2002). Epigenetic reprogramming in mouse primordial germ cells. Mech Dev 117: 15-23

HAJKOVA, P., JEFFRIES, S.J., LEE, C., MILLER, N., JACKSON, S.P. and SURANI, M.A. (2010). Genome-wide reprogramming in the mouse germ line entails the base excision repair pathway. Science 329: 78-82.

HAMMOUD, S.S., NIX, D.A., HAMMOUD, A.O., GIBSON, M., CAIRNS, B.R. and CARRELL, D.T. (2011). Genome-wide analysis identifies changes in histone retention and epigenetic modifications at developmental and imprinted gene loci in the sperm of infertile men. Hum Reprod 26: 2558-2569.

HAMMOUD, S.S., NIX, D.A., ZHANG, H., PURWAR, J., CARRELL, D.T. and CAIRNS, B.R. (2009). Distinctive chromatin in human sperm packages genes for embryo development. Nature 460: 473-478.

HAWKINS, R.D., HON, G.C., YANG, C., ANTOSIEWICZ-BOURGET, J.E., LEE, L.K., NGO, Q.M., KLUGMAN, S., CHING, K.A., EDSALL, L.E., YE, Z. et al., (2011). Dynamic chromatin states in human ES cells reveal potential regulatory sequences and genes involved in pluripotency. Cell Res 21: 1393-1409.

HAYASHI, K., DE SOUSA LOPES, S.M. and SURANI, M.A. (2007). Germ cell specification in mice. Science 316: 394-396.

HERBST, A.L., ULFELDER, H. and POSKANZER, D.C. (1971). Adenocarcinoma of the vagina. Association of maternal stilbestrol therapy with tumor appearance in young women. N Engl J Med 284: 878-881.

HERSMUS, R., STOOP, H., VAN DE GEIJN, G.J., EINI, R., BIERMANN, K., OOSTERHUIS, J.W., DHOOGE, C., SCHNEIDER, D.T., MEIJSSEN, I.C., DINJENS, W.N.M. et al., (2012). Prevalence of c-KIT Mutations in Gonadoblastoma and Dysgerminomas of Patients with Disorders of Sex Development (DSD) and Ovarian Dysgerminomas. PLoS One 7: e43952.

HOLM, T.M., JACKSON-GRUSBY, L., BRAMBRINK, T., YAMADA, Y., RIDEOUT, W.M., 3RD and JAENISCH, R. (2005). Global loss of imprinting leads to widespread tumorigenesis in adult mice. Cancer Cell 8: 275-285.

HONECKER, F., STOOP, H., MAYER, F., BOKEMEYER, C., CASTRILLON, D.H., LAU, Y.F., LOOIJENGA, L.H. and OOSTERHUIS, J.W. (2006). Germ cell lineage differentiation in non-seminomatous germ cell tumours. J Pathol 208: 395-400.

HONORIO, S., AGATHANGGELOU, A., WERNERT, N., ROTHE, M., MAHER, E.R. and LATIF, F. (2003). Frequent epigenetic inactivation of the RASSF1A tumour suppressor gene in testicular tumours and distinct methylation profiles of seminoma and nonseminoma testicular germ cell tumours. Oncogene 22: 461-466.

HUYGHE, E., MATSUDA, T. and THONNEAU, P. (2003). Increasing incidence of testicular cancer worldwide: a review. J Urol 170: 5-11.

HUYGHE, E., PLANTE, P. and THONNEAU, P.F. (2007). Testicular cancer variations in time and space in Europe. Eur Urol 51: 621-628.

JONES, P.A. (2012). Functions of DNA methylation: islands, start sites, gene bodies and beyond. Nat Rev Genet 13: 484-492.

JONES, P.A. and LIANG, G. (2009). Rethinking how DNA methylation patterns are maintained. Nat Rev Genet 10: 805-811.

KAWAKAMI, T., OKAMOTO, K., OGAWA, O. and OKADA, Y. (2004). XIST unmethylated DNA fragments in male-derived plasma as a tumour marker for testicular cancer. Lancet 363: 40-42.

KAZAZIAN, H.H., JR. (2004). Mobile elements: drivers of genome evolution. Science 303: 1626-1632.

KORKOLA, J.E., HOULDSWORTH, J., DOBRZYNSKI, D., OLSHEN, A.B., REUTER, V.E., BOSL, G.J. and CHAGANTI, R.S. (2005). Gene expression-based classification of nonseminomatous male germ cell tumors. Oncogene 24: 5101-5107.

KOUL, S., MCKIERNAN, J.M., NARAYAN, G., HOULDSWORTH, J., BACIK, J., DOBRZYNSKI, D.L., ASSAAD, A.M., MANSUKHANI, M., REUTER, V.E., BOSL, G.J. et al., (2004). Role of promoter hypermethylation in Cisplatin treatment response of male germ cell tumors. Mol Cancer 3: 16.

KREGE, S., BEYER, J., SOUCHON, R., ALBERS, P., ALBRECHT, W., ALGABA, F., BAMBERG, M., BODROGI, I., BOKEMEYER, C., CAVALLIN-STAHL, E. et al., (2008). European consensus conference on diagnosis and treatment of germ cell cancer: a report of the second meeting of the European Germ Cell Cancer Consensus group (EGCCCG): part I. Eur Urol 53: 478-496.

KUTANZI, K.R., KOTURBASH, I. and KOVALCHUK, O. (2010). Reversibility of pre-malignant estrogen-induced epigenetic changes. Cell Cycle 9: 3078-3084.

LANDER, E.S.LINTON, L.M.BIRREN, B.NUSBAUM, C.ZODY, M.C.BALDWIN,
J.DEVON, K.DEWAR, K.DOYLE, M.FITZHUGH, W. et al., (2001). Initial sequencing and analysis of the human genome. Nature 409: 860-921.

LANG-MLADEK, C., POPOVA, O., KIOK, K., BERLINGER, M., RAKIC, B., AUFSATZ, W., JONAK, C., HAUSER, M.T. and LUSCHNIG, C. (2010). Transgenerational inheritance and resetting of stress-induced loss of epigenetic gene silencing in Arabidopsis. Mol Plant 3: 594-602.

LEE, H.C., GU, W., SHIRAYAMA, M., YOUNGMAN, E., CONTE, D., JR. and MELLO, C.C. (2012). C. elegans piRNAs Mediate the Genome-wide Surveillance of Germline Transcripts. Cell. 150: 78-87.

LI, E., BESTOR, T.H. and JAENISCH, R. (1992). Targeted mutation of the DNA methyltransferase gene results in embryonic lethality. Cell 69: 915-926.

LISTER, R., PELIZZOLA, M., DOWEN, R.H., HAWKINS, R.D., HON, G., TONTIFILIPPINI, J., NERY, J.R., LEE, L., YE, Z., NGO, Q.M. et al., (2009). Human DNA methylomes at base resolution show widespread epigenomic differences. Nature 462: 315-322.

LONGNECKER, M.P., KLEBANOFF, M.A., BROCK, J.W., ZHOU, H., GRAY, K.A., NEEDHAM, L.L. and WILCOX, A.J. (2002). Maternal serum level of 1,1-dichloro-2,2-bis(p-chlorophenyl)ethylene and risk of cryptorchidism, hypospadias, and polythelia among male offspring. Am J Epidemiol 155: 313-322.

LOOIJENGA, L.H., GILLIS, A.J., STOOP, H., BIERMANN, K. and OOSTERHUIS, J.W. (2011). Dissecting the molecular pathways of (testicular) germ cell tumour pathogenesis; from initiation to treatment-resistance. Int J Androl 34: e234-e251.

LOOIJENGA, L.H., GILLIS, A.J., VAN GURP, R.J., VERKERK, A.J. and OOSTERHUIS, J.W. (1997). X inactivation in human testicular tumors. XIST expression and androgen receptor methylation status. Am J Pathol 151: 581-590.

LOOIJENGA, L.H., HERSMUS, R., GILLIS, A.J., PFUNDT, R., STOOP, H.J., VAN GURP, R.J., VELTMAN, J., BEVERLOO, H.B., VAN DRUNEN, E., VAN KESSEL, A.G. et al., (2006). Genomic and expression profiling of human spermatocytic seminomas: primary spermatocyte as tumorigenic precursor and DMRT1 as candidate chromosome 9 gene. Cancer Res 66: 290-302.

LOOIJENGA, L.H., STOOP, H., DE LEEUW, H.P., DE GOUVEIA BRAZAO, C.A., GILLIS, A.J., VAN ROOZENDAAL, K.E., VAN ZOELEN, E.J., WEBER, R.F., WOLFFENBUTTEL, K.P., VAN DEKKEN, H. et al., (2003). POU5F1 (OCT3/4) identifies cells with pluripotent potential in human germ cell tumors. Cancer Res 63: 2244-2250.

MANSOUR, A.A., GAFNI, O., WEINBERGER, L., ZVIRAN, A., AYYASH, M., RAIS, Y., KRUPALNIK, V., ZERBIB, M., AMANN-ZALCENSTEIN, D., MAZA, I. et al., (2012). The H3K27 demethylase Utx regulates somatic and germ cell epigenetic reprogramming. Nature 488: 409-413.

MANTON, K.J., DOUGLAS, M.L., NETZEL-ARNETT, S., FITZPATRICK, D.R., NICOL, D.L., BOYD, A.W., CLEMENTS, J.A. and ANTALIS, T.M. (2005). Hypermethylation of the 5' $\mathrm{CpG}$ island of the gene encoding the serine protease Testisin promotes its loss in testicular tumorigenesis. Br J Cancer 92: 760-769.

MAYER, F., HONECKER, F., LOOIJENGA, L.H. and BOKEMEYER, C. (2003). Towards an understanding of the biological basis of response to cisplatin-based chemotherapy in germ-cell tumors. Ann Oncol 14: 825-832.

MCINTYRE, A., GILBERT, D., GODDARD, N., LOOIJENGA, L. and SHIPLEY, J. (2008). Genes, chromosomes and the development of testicular germ cell tumors of adolescents and adults. Genes Chromosomes Cancer 47: 547-457.

MCLAREN, A. (2003). Primordial germ cells in the mouse. Dev Biol 262: 1-15.

MELNYK, C.W., MOLNAR, A. and BAULCOMBE, D.C. (2011). Intercellular and systemic movement of RNA silencing signals. EMBO J 30: 3553-3563.

MILLAN, J.L. and FISHMAN, W.H. (1995). Biology of human alkaline phosphatases with special reference to cancer. Crit Rev Clin Lab Sci 32: 1-39.

MINAMI, K., CHANO, T., KAWAKAMI, T., USHIDA, H., KUSHIMA, R., OKABE, H. OKADA, Y. and OKAMOTO, K. (2010). DNMT3L is a novel marker and is essential for the growth of human embryonal carcinoma. Clin Cancer Res 16: 2751-2759.

MORAIS DA SILVA, S., HACKER, A., HARLEY, V., GOODFELLOW, P., SWAIN, A and LOVELL-BADGE, R. (1996). Sox9 expression during gonadal development implies a conserved role for the gene in testis differentiation in mammals and birds. Nat Genet 14: 62-68.

NELSON, V.R., HEANEY, J.D., TESAR, P.J., DAVIDSON, N.O. and NADEAU, J.H. (2012). Transgenerational epigenetic effects of the Apobec1 cytidine deaminase deficiency on testicular germ cell tumor susceptibility and embryonic viability. Proc Natl Acad Sci USA 109: E2766-E2773. 
NETTO, G.J., NAKAI, Y., NAKAYAMA, M., JADALLAH, S., TOUBAJI, A., NONOMURA, N., ALBADINE, R., HICKS, J.L., EPSTEIN, J.I., YEGNASUBRAMANIAN, S. et al., (2008). Global DNA hypomethylation in intratubular germ cell neoplasia and seminoma, but not in nonseminomatous male germ cell tumors. Mod Pathol 21: 1337-1344.

OGUNBIYI, J.O., SHITTU, O.B., AGHADIUNO, P.U. and LAWANI, J. (1996). Seminoma arising in cryptorchid testes in Nigerian males. East Afr Med J 73: 129-132.

OHINATA, Y., PAYER, B., O'CARROLL, D., ANCELIN, K., ONO, Y., SANO, M., BARTON, S.C., OBUKHANYCH, T., NUSSENZWEIG, M., TARAKHOVSKY, A. et al., (2005). Blimp1 is a critical determinant of the germ cell lineage in mice. Nature 436: 207-213.

OKAMOTO, K. and KAWAKAMI, T. (2007). Epigenetic profile of testicular germ cell tumours. Int J Androl 30: 385-392; discussion 392.

OKANO, M., BELL, D.W., HABER, D.A. and LI, E. (1999). DNA methyltransferases Dnmt3a and Dnmt3b are essential for de novo methylation and mammalian development. Cell 99: 247-257.

OLIVA, R., BAZETT-JONES, D., MEZQUITA, C. and DIXON, G.H. (1987). Factors affecting nucleosome disassembly by protamines in vitro. Histone hyperacetylation and chromatin structure, time dependence, and the size of the sperm nuclear proteins. J Biol Chem 262: 17016-17025.

OOSTERHUIS, J.W. and LOOIJENGA, L.H. (2005). Testicular germ-cell tumours in a broader perspective. Nat Rev Cancer 5: 210-222.

OOSTERHUIS, J.W., LOOIJENGA, L.H., VAN ECHTEN, J. and DE JONG, B. (1997). Chromosomal constitution and developmental potential of human germ cell tumors and teratomas. Cancer Genet Cytogenet 95: 96-102.

PARK, Y.J., CLAUS, R., WEICHENHAN, D. and PLASS, C. (2011). Genome-wide epigenetic modifications in cancer. Prog Drug Res 67: 25-49.

POPP, C., DEAN, W., FENG, S., COKUS, S.J., ANDREWS, S., PELLEGRINI, M., JACOBSEN, S.E. and REIK, W. (2010). Genome-wide erasure of DNAmethylation in mouse primordial germ cells is affected by AID deficiency. Nature 463:1101-1105.

PRICKETT, A.R. and OAKEY, R.J. (2012). A survey of tissue-specific genomic imprinting in mammals. Mol Genet Genomics 287: 621-630.

RADA-IGLESIAS, A., BAJPAI, R., SWIGUT, T., BRUGMANN, S.A., FLYNN, R.A. and WYSOCKA, J. (2011). A unique chromatin signature uncovers early developmental enhancers in humans. Nature 470: 279-283.

RAPLEY, E.A., TURNBULL, C., AL OLAMA, A.A., DERMITZAKIS, E.T., LINGER, R., HUDDART, R.A., RENWICK, A., HUGHES, D., HINES, S., SEAL, S. et al., (2009). A genome-wide association study of testicular germ cell tumor. Nat Genet 41: 807-810.

RASSOULZADEGAN, M. and CUZIN, F. (2010). The making of an organ: RNA mediated developmental controls in mice. Organogenesis 6: 33-36.

REIK, W. and WALTER, J. (2001). Genomic imprinting: parental influence on the genome. Nat Rev Genet 2: 21-32.

ROSENBERG, B., VANCAMP, L. and KRIGAS, T. (1965). Inhibition of Cell Division in Escherichia Coli by Electrolysis Products from a Platinum Electrode. Nature 205: 698-699

SALIDO, E.C., YEN, P.H., MOHANDAS, T.K. and SHAPIRO, L.J. (1992). Expression of the X-inactivation-associated gene XIST during spermatogenesis. Nat Genet 2: 196-199.

SAPIENZA, C., PETERSON, A.C., ROSSANT, J. and BALLING, R. (1987). Degree of methylation of transgenes is dependent on gamete of origin. Nature 328:251-254.

SASAKI, H. and MATSUI, Y. (2008). Epigenetic events in mammalian germ-cell development: reprogramming and beyond. Nat Rev Genet 9: 129-140.

SCHOLER, H.R., RUPPERT, S., SUZUKI, N., CHOWDHURY, K. and GRUSS, P. (1990). New type of POU domain in germ line-specific protein Oct-4. Nature 344: 435-439.

SCHUSTER-BOCKLER, B. and LEHNER, B. (2012). Chromatin organization is a major influence on regional mutation rates in human cancer cells. Nature.

SEKI, Y., YAMAJI, M., YABUTA, Y., SANO, M., SHIGETA, M., MATSUI, Y., SAGA, Y., TACHIBANA, M., SHINKAI, Y. and SAITOU, M. (2007). Cellular dynamics associated with the genome-wide epigenetic reprogramming in migrating primordial germ cells in mice. Development 134: 2627-2638.

SHAHHOSEINI, M., TAEI,A., MEHRJARDI, N.Z., SALEKDEH, G.H. and BAHARVAND,
H. (2010). Epigenetic analysis of human embryonic carcinoma cells during retinoic acid-induced neural differentiation. Biochem Cell Biol 88: 527-538.

SHARPE, R.M. and SKAKKEBAEK, N.E. (1993). Are oestrogens involved in falling sperm counts and disorders of the male reproductive tract? Lancet341: 1392-1395.

SHIRAYAMA, M., SETH, M., LEE, H.C., GU, W., ISHIDATE, T., CONTE, D., JR. and MELLO, C.C. (2012). piRNAs Initiate an Epigenetic Memory of Nonself RNA in the C. elegans Germline. Cell 150: 65-77

SKAKKEBAEK, N.E., RAJPERT-DE MEYTS, E. and MAIN, K.M. (2001). Testicular dysgenesis syndrome: an increasingly common developmental disorder with environmental aspects. Hum Reprod 16: 972-978.

SMIRAGLIA, D.J., SZYMANSKA, J., KRAGGERUD, S.M., LOTHE, R.A., PELTOMAKI, P. and PLASS, C. (2002). Distinct epigenetic phenotypes in seminomatous and nonseminomatous testicular germ cell tumors. Oncogene 21: 3909-3916.

SPIERINGS, D.C., DE VRIES, E.G., STEL, A.J., TE RIETSTAP, N., VELLENGA, E. and DE JONG, S. (2004). Low p21Waf1/Cip1 protein level sensitizes testicular germ cell tumor cells to Fas-mediated apoptosis. Oncogene 23: 4862-4872.

STOOP, H., KIRKELS, W., DOHLE, G.R., GILLIS, A.J., DEN BAKKER, M.A., BIERMANN, K., OOSTERHUIS, W. and LOOIJENGA, L.H. (2011). Diagnosis of testicular carcinoma in situ '(intratubular and microinvasive)' seminoma and embryonal carcinoma using direct enzymatic alkaline phosphatase reactivity on frozen histological sections. Histopathology 58: 440-446.

STORGAARD, L., BONDE, J.P. and OLSEN, J. (2006). Male reproductive disorders in humans and prenatal indicators of estrogen exposure. A review of published epidemiological studies. Reprod Toxicol 21: 4-15.

STRAHL, B.D. and ALLIS, C.D. (2000). The language of covalent histone modifications. Nature 403: 41-45.

STROHSNITTER, W.C., NOLLER, K.L., HOOVER, R.N., ROBBOY, S.J., PALMER, J.R., TITUS-ERNSTOFF, L., KAUFMAN, R.H., ADAM, E., HERBST, A.L. and HATCH, E.E. (2001). Cancer risk in men exposed in utero to diethylstilbestrol. $\checkmark$ Natl Cancer Inst 93: 545-551.

SUGIMURA, J., FOSTER, R.S., CUMMINGS, O.W., KORT, E.J., TAKAHASHI, M. LAVERY, T.T., FURGE, K.A., EINHORN, L.H. and TEH, B.T. (2004). Gene expression profiling of early- and late-relapse nonseminomatous germ cell tumor and primitive neuroectodermal tumor of the testis. Clin Cancer Res 10: 2368-2378.

SUSNERWALA, S.S., PANDE, S.C., SHRIVASTAVA, S.K. and DINSHAW, K.A (1991). Dysgerminoma of the ovary: review of 27 cases. J Surg Oncol 46: 43-47.

SWAIN, J.L., STEWART, T.A. and LEDER, P. (1987). Parental legacy determines methylation and expression of an autosomal transgene: a molecular mechanism for parental imprinting. Cell 50: 719-727.

TAHILIANI, M., KOH, K.P., SHEN, Y., PASTOR, W.A., BANDUKWALA, H., BRUDNO Y., AGARWAL, S., IYER, L.M., LIU, D.R., ARAVIND, L. et al., (2009). Conversion of 5-methylcytosine to 5-hydroxymethylcytosine in mammalian DNA by MLL partner TET1. Science 324: 930-935.

TSUMURA, A., HAYAKAWA, T., KUMAKI, Y., TAKEBAYASHI, S., SAKAUE, M., MATSUOKA, C., SHIMOTOHNO, K., ISHIKAWA, F., LI, E., UEDA, H.R. et al., (2006). Maintenance of self-renewal ability of mouse embryonic stem cells in the absence of DNA methyltransferases Dnmt1, Dnmt3a and Dnmt3b. Genes Cells 11:805-814.

UHLENHAUT, N.H. and TREIER, M. (2006). Foxl2 function in ovarian development Mol Genet Metab 88: 225-234.

USHIDA, H., KAWAKAMI, T., MINAMI, K., CHANO, T., OKABE, H., OKADA, Y. and OKAMOTO, K. (2012). Methylation profile of DNA repetitive elements in human testicular germ cell tumor. Mol Carcinog. 51: 711-722.

WATANABE, T., TAKEDA, A., TSUKIYAMA, T., MISE, K., OKUNO, T., SASAKI, H., MINAMI, N. and IMAI, H. (2006). Identification and characterization of two nove classes of small RNAs in the mouse germline: retrotransposon-derived siRNAs in oocytes and germline small RNAs in testes. Genes Dev 20: 1732-1743.

WERMANN, H., STOOP, H., GILLIS, A.J., HONECKER, F., VAN GURP, R.J., AMMERPOHL, O., RICHTER, J., OOSTERHUIS, J.W., BOKEMEYER, C. and LOOIJENGA, L.H. (2010). Global DNA methylation in fetal human germ cells and germ cell tumours: association with differentiation and cisplatin resistance. J Pathol 221: 433-442.

YANG, J.K. (2008). FLIP as an anti-cancer therapeutic target. Yonsei Med J 49: 19-27. YOUNG, R.A. (2011). Control of the embryonic stem cell state. Cell 144: 940-954. 


\section{Further Related Reading, published previously in the Int. J. Dev. Biol.}

Germline stem cells and sex determination in Hydra

Chiemi Nishimiya-Fujisawa and Satoru Kobayashi

Int. J. Dev. Biol. (2012) 56: 499-508

The Dr-nanos gene is essential for germ cell specification in the planarian Dugesia ryukyuensis

Haruka Nakagawa, Hirotsugu Ishizu, Ayako Chinone, Kazuya Kobayashi and Midori Matsumoto Int. J. Dev. Biol. (2012) 56: 165-171

In vitro germ cell differentiation during sex differentiation in a teleost fish Tohru Kobayashi

Int. J. Dev. Biol. (2010) 54: 105-111

mgm 1, the earliest sex-specific germline marker in Drosophila, reflects expression of the gene esg in male stem cells

Adrian Streit, Luca Bernasconi, Pavel Sergeev, Alex Cruz and Monica Steinmann-Zwicky Int. J. Dev. Biol. (2002) 46: 159-166

Differentiation of mouse primordial germ cells into female or male germ cells N Nakatsuji and S Chuma

Int. J. Dev. Biol. (2001) 45: 541-548

5 yr ISI Impact Factor $(2011)=2.959$

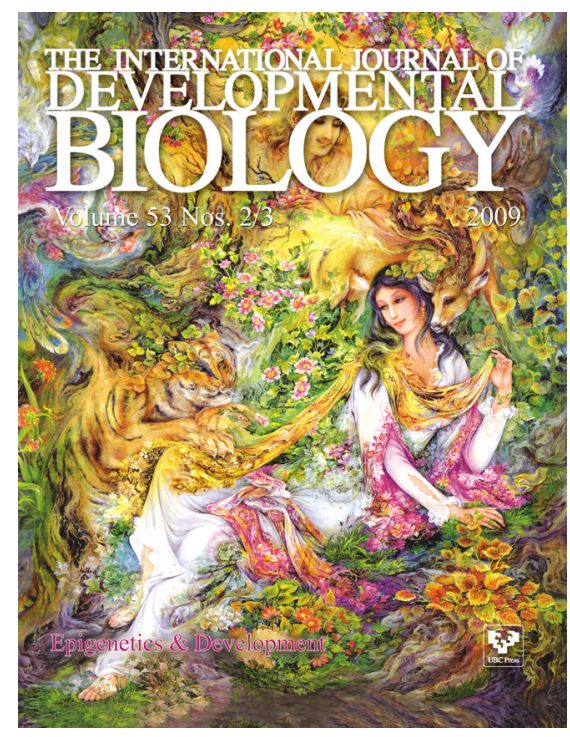

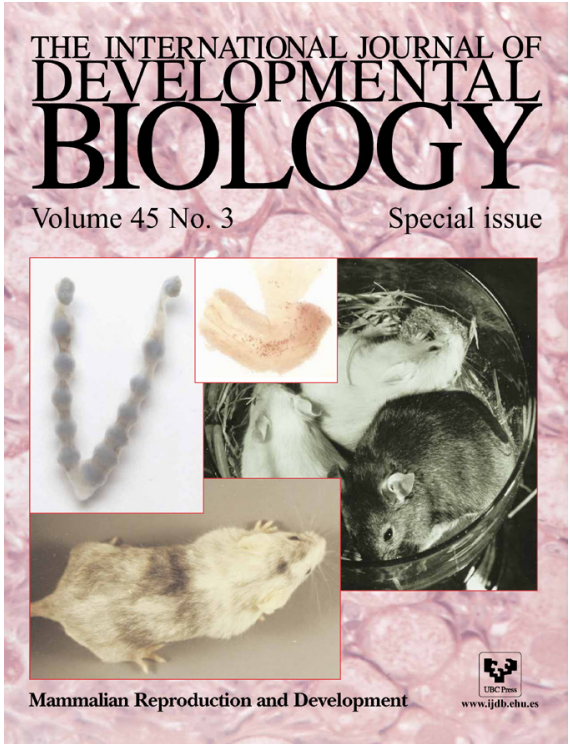

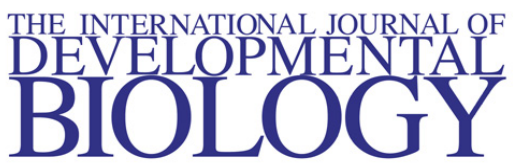

Volume 48 Nos. $5 / 6$

Special issue

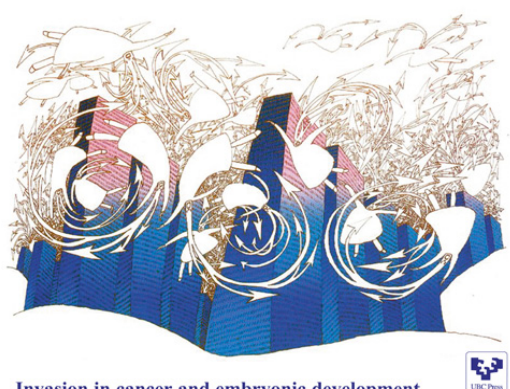

Invasion in cancer and embryonic development

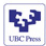

